Jurnal Sistem Informasi (Journal of Information Systems). 2/13 (2017), 110-117

DOI: http://dx.doi.org/10.21609/jsi.v13i2.546

\title{
WEB-BASED EXPERT SYSTEM APPLICATION TO RECOMMEND COMPUTER SPECIFICATIONS FOR GAMING USING BACKWARD CHAINING INFERENCE METHOD
}

\author{
${ }^{1}$ Gottfried Christophorus Prasetyadi dan ${ }^{2}$ Mahfudin \\ Faculty of Computer Science and Information Technology, Gunadarma University, J1. Margonda Raya \\ 100, Depok, 16424, Indonesia \\ E-mail: ${ }^{1}$ gottfriedcpn@gmail.com, ${ }^{2}$ mahfudin.ug@gmail.com
}

\begin{abstract}
This study aims to design and implement an expert system application to provide minimum computer hardware and operating system requirements, which are capable of running games with certain graphical settings. Backward chaining inference method is used to conclude the output, which the requirements are based on user's input. The application is made using PHP general-purpose server-side scripting language and MySQL database. By using this application, a user can consult as well as to an expert to know the computer specifications capable of running a game with preferred graphical settings and to estimate the cost to build that computer. This application can also help sellers of computer parts to set price on the custom-built computers, to create category or sales package, as well as to provide information for potential buyers.
\end{abstract}

Keywords: expert system, gaming, computer specifications, backward chaining

\begin{abstract}
Abstrak
Penelitian ini bertujuan untuk merancang dan menerapkan aplikasi sistem pakar untuk menyediakan perangkat keras minimum yang dibutuhkan untuk merakit sebuah komputer dan persyaratan sistem operasi yang mampu menjalankan permainan dengan pengaturan grafis tertentu. Metode inferensi backward-chaining digunakan untuk menyimpulkan output, yang dihasilkan berdasarkan input pengguna. Aplikasi ini dibuat dengan menggunakan bahasa scripting untuk fungsi umum pada sisi server yaitu PHP dan database MySQL. Dengan menggunakan aplikasi ini, pengguna bisa berkonsultasi dengan ahli yang mengetahui spesifikasi komputer yang mampu menjalankan game dengan pengaturan grafis yang disukai dan memberikan perkiraan harga yang tepat untuk merakit komputer tersebut. Aplikasi ini juga dapat membantu para penjual bagian-bagian komputer dalam menetapkan harga komputer rakitan, membuat kategori atau paket penjualan, serta memberikan informasi kepada calon pembeli.
\end{abstract}

Kata Kunci: expert system, gaming, computer specifications, backward chaining

\section{Introduction}

Expert systems as part of artificial intelligence (AI) technology can be used in various specific areas. In the field of multimedia and entertainment, many people experience problems in how to know the exact minimum requirements of hardware and software suitable enough to run various computer/PC games. With the continuous discovery of new techniques in graphics rendering and the development of technology in graphics processing devices with the aim that the game can look as real, it forces PC game to choose computer components more carefully. The selection is intended so the computer can run a variety of games and their graphics features for a long time, considering the economic motive.

A game always has a minimum system requirement. For example, Dirt 3, an off-road racing ga- me that was released in 2011, has a minimum system requirement of Intel Pentium $2.8 \mathrm{GHz}$ processsor, 2 GB of RAM, NVIDIA GeForce 8000 graphics processor, and Microsoft Windows XP operating system. The game would run well on such system, with acceptable framerate. Running the game on the system that has weaker system specifications will decrease the quality of gameplay, for example: poor image quality, lag, bad audio quality, and constant system crash. Spending money to build high-end, expensive computer to satisfy those needs is not always an option. Every game player has preferred graphics features to activate based on their desire, and still ful-fill it economically.

Based on the background above, a knowledge-based system of graphical features and computer software and hardware technologies will be de- 
TABLE 1

\begin{tabular}{|c|c|c|}
\hline Feature & Level & Point \\
\hline \multirow[t]{2}{*}{ Screen resolution } & $1280 \times 720$ & 1 \\
\hline & $1920 \times 1080$ & 2 \\
\hline \multirow{2}{*}{ VSync } & off & 0 \\
\hline & on & 1 \\
\hline \multirow[t]{3}{*}{ Shader quality } & normal & 1 \\
\hline & high & 2 \\
\hline & very high & 3 \\
\hline \multirow[t]{2}{*}{ FXAA } & off & 0 \\
\hline & on & 1 \\
\hline \multirow[t]{3}{*}{ MSAA } & $2 x$ & 1 \\
\hline & $4 x$ & 2 \\
\hline & $8 x$ & 4 \\
\hline \multirow[t]{2}{*}{ TXAA } & $2 x$ & 2 \\
\hline & $4 x$ & 4 \\
\hline \multirow[t]{3}{*}{ Ambient Occlusion } & off & 0 \\
\hline & normal & 1 \\
\hline & high & 2 \\
\hline \multirow[t]{3}{*}{ Texture quality } & normal & 1 \\
\hline & high & 2 \\
\hline & very high & 3 \\
\hline \multirow[t]{4}{*}{ Tessellation } & off & 0 \\
\hline & normal & 1 \\
\hline & high & 2 \\
\hline & very high & 3 \\
\hline
\end{tabular}

veloped. The system aims to let users know the minimum requirements of hardware and software to run a game with its graphical features. Through the user interface of the application, the user can select one of several games that represents their genre (such as racing, action, strategy, etc.) and choose the preferred graphical features that will be activeted in game. The data entered by the user is then processed based on the knowledge base that has been set up previously, and finally, the user gets a list of selection of cheapest computer systems that are able to run the game smoothly. By using the application, users are expected to feel like consulting with a real computer expert.

\section{Method}

Data collection is done by studying general game graphics features and rendering process, how much they affect overall system performance, and information about computer components and peripheral through various literatures such as website article, journals, and other sources. Only common graphics features are used in this research. Sources from graphics processor manufacturer such as NVIDIA Corporation and gaming enthusiast website such as GameSpot are proven thorough and detailed, and they are mostly available online. They are used as consideration in assigning points explained later in this writing. For the basics and theory of expert system, some older references are still used, as their contents are still relevant today. Several related papers about expert systems were also studied.
TABLE 2

\begin{tabular}{|c|c|}
\hline Antecedent & Consequent \\
\hline $\begin{array}{l}\text { IF } \quad x \quad \text { HAS fea- } \\
\text { tures_sum }<=5\end{array}$ & THEN x IS SPEC_MIN \\
\hline $\begin{array}{l}\text { IF } \quad \text { X HAS fea- } \\
\text { tures_sum }>5 \text { AND } \\
\text { features_sum }<14\end{array}$ & THEN x IS SPEC_MED \\
\hline $\begin{array}{l}\text { IF } x \text { HAS fea- } \\
\text { tures_sum }>=14\end{array}$ & THEN x IS SPEC_MAX \\
\hline IF $x$ IS SPEC_MIN & $\begin{array}{l}\text { THEN x HAS ( } \\
\text { (cpu IS cpu1) AND } \\
\text { (gpu IS gpu1) AND } \\
\text { (ram IS ram1) AND } \\
\ldots \\
\text { (estimated_price IS price1) }\end{array}$ \\
\hline IF $x$ IS SPEC_MED & $\begin{array}{l}\text { THEN x HAS ( } \\
\text { (cpu IS cpu2) AND } \\
\text { (gpu IS gpu2) AND } \\
\text { (ram IS ram2) AND } \\
\ldots \\
\text { (estimated_price IS price2) }\end{array}$ \\
\hline IF x IS SPEC_MAX & $\begin{array}{l}\text { THEN x HAS ( } \\
\text { (cpu IS cpu3) AND } \\
\text { (gpu IS gpu3) AND } \\
\text { (ram IS ram3) AND } \\
\ldots \\
\text { (estimated_price IS price3) }\end{array}$ \\
\hline
\end{tabular}

\section{Similar Researches}

We reviewed some related researches that used methods and implementations similar to ours. [1] provided information in the form of diagnosis and initial solutions for every type of anxiety disorder that was diagnosed, using forward chaining method and Best-First Search technique. It also utilized similar database scheme and implementtation tools.

[2] created a decision support system to diagnose Diabetes Mellitus with Fuzzy Inference System (FIS) Mamdani. Samples were taken from six puskesmas from East Jakarta. It used Matlab with user interface for implementation. However, it did not state clearly whether the data for the variables could be updated dynamically, though it claimed that the trial results are $100 \%$ in accordance with doctors' diagnoses.

Last, [3] created an expert system to give initial diagnosis of skin disease in cats using certainty factor method. Similar to this research, it utilized point system during consultation session to generate conclusion, which was certainty factor value.

\section{Expert System}

Expert systems or knowledge-based systems are part of artificial intelligence that allows computers to process and derive conclusions from a set of rules [4]. The purpose of expert system development 
TABLE 3

\begin{tabular}{lll}
\multicolumn{3}{c}{ AVAILABLE PC GAMES } \\
\hline Field & \multicolumn{1}{c}{ Type } & \multicolumn{1}{c}{ Key } \\
\hline id & int & primary \\
name & varchar & \\
genre & int & foreign \\
developer & int & foreign \\
publisher & int & foreign \\
producer & int & foreign \\
engine & varchar & \\
release_year & int & \\
description & text & \\
\hline
\end{tabular}

This is the structure of the table before undergoing normalization, as it is obvious that there can be multiple genre, publisher, etc. for each game (many-to-many).

\begin{tabular}{lll}
\multicolumn{3}{c}{ TABLE 4 } \\
& FEATURE POINT & \\
\hline \multicolumn{1}{c}{ Field } & \multicolumn{1}{c}{ Type } & Key \\
\hline id & int & primary \\
feature_id & int & foreign \\
level & varchar & \\
point & int & \\
\hline $\begin{array}{l}\text { The features' name and brief description are stored in sep- } \\
\text { arate table, and one feature may have multiple level and } \\
\text { point, thus the foreign as the result of normalization. }\end{array}$
\end{tabular}

is to produce a system that can assist human work, especially in relation to the utilization of expertise and experience in a particular field. There are three main parts of artificial intelligence, i.e. knowledge base, inference engine, and user interface. The following are the detail explanation:

Knowledge base (KB)

$\mathrm{KB}$ contains all facts, ideas, relationships, and rules of the problem domain. In this case, these facts are knowledge (as data) of the minimum system requirements capable of running every available game features.

\section{Inference engine (IE)}

IE is used to analyze inputs based on acquired knowledge and rules in the expert system, and draw conclusions from them. In analyzing, the inference engine uses a particular technique that corresponds to the field and purpose of the expert system.

User interface (UI)

UI acts as an interaction media between the expert system and the user. In this case, the user can select one of several available games and choose what features are desired. All those inputs are given by the user through the user interface, and afterwards, the user gets the conclusions from the expert system that can be used as a reference.

\section{Backward Chaining Inference Method}

Backward chaining (goal driven) method is a problem-solving method used by expert systems, by specifying goals and proving that this goal can be
TABLE 5

\begin{tabular}{lll}
\multicolumn{3}{c}{ CPU SPECIFICATION } \\
\hline Field & Type & Key \\
\hline id & int & primary \\
name & varchar & \\
manufacturer & varchar & \\
spec_cluster & varchar(3) \\
point & int & \\
The 'spec_cluster' holds three fixed values: MIN, MED, \\
and HIG.
\end{tabular}

TABLE 6

PREFERREd GRAPHICS SETTINGS FOR GTA V

\begin{tabular}{lll}
\multicolumn{1}{c}{ Features } & Level value & point \\
\hline Screen resolution & $1280 \times 720$ & 1 \\
VSync & on & 1 \\
Shader quality & normal & 1 \\
FXAA & on & 1 \\
MSAA & $2 \mathrm{x}$ & 1 \\
TXAA & off & 0 \\
Ambient Occlusion & normal & 1 \\
Texture quality & high & 2 \\
Tessellation & off & 0 \\
\hline & features_sum & 8 \\
\hline
\end{tabular}

achieved in accordance with rules by checking its knowledge base [5]. This technique is appropriate for consultation and recommendation expert systems such as in this research.

\section{Graphics Features in Computer Games}

There are several graphics settings and features found in modern games:

Screen resolution

It is the ratio of the number of horizontal pixels to the number of vertical pixels on the screen. The higher the resolution, the more pixels appear on the screen, which means the image will be more detailed.

\section{Vertical Synchronization (VSync)}

VSync is a technique used to prevent screen tearing that is characterized by misalignments of objects in the image displayed on screen. This occurs because the monitor has to display the next frame before it can even display the current frame completely.

\section{Shader quality}

Shader quality affects lighting, such as the lighting effect on the object surface and the realism level of light emitted by the objects [6].

\section{Antialiasing}

It is used to reduce the effect of aliasing (stair-step effect) in the image. Aliasing can be seen easily at an object with diagonal lines or curves, causing a decrease in image quality. Two examples of antialiasing are FXAA (Fast Approximate Antialiasing) [7] and TXAA (Temporal Antialiasing) [8]. 


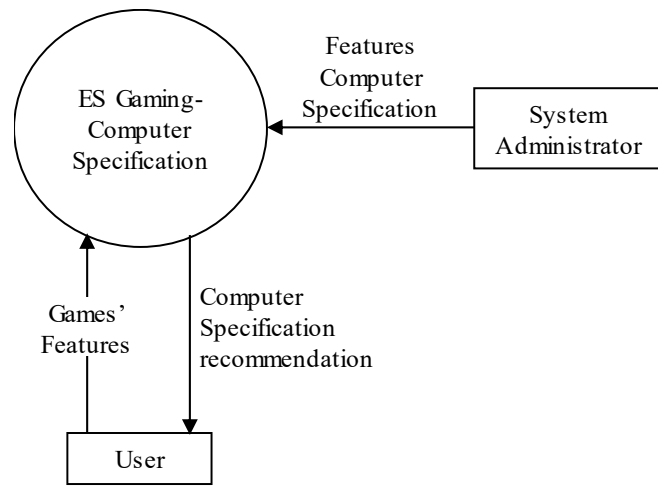

Figure 1. Context diagram

Ambient occlusion

It adds contact shadows on two adjacent object surfaces and blocks the light obstructed by an object from reaching other objects [6].

\section{Texture quality}

It affects how detailed textures are rendered. The higher the quality, the greater the memory needed by the graphics processing unit (GPU).

\section{Tessellation}

This feature makes a flat surface seems to be more detailed by giving a difference in texture depth to that object [9].

\section{Point Assignment for Graphics Features}

The assignment of points/score considers the following: 1) Each feature may have different activation options, such as ON or OFF only, or it could be with a quality level, such as Low, Medium, and High; 2) Each feature has its own terms of hardware requirements and the API (Application Programming Interface) supported by the operating system, such as DirectX and OpenGL; 3) Enabling a graphics feature at high level requires increased processing time depending on the hardware. It may result in reduced frame rate; 4) The points and fair value limits that later distinguish the recommendations output are based on the conclusions derived from various literature studies; 5) Points are added to features_sum variable, which always have a starting value of 0 and it always increases in value each time the user selects a feature. This variable is used as a fact or main variable that will be processsed for drawing conclusions.

\section{Rules}

The goals are computers with certain specifications, shown as a list of hardware components, operating system, and estimated price (in Rupiah) to

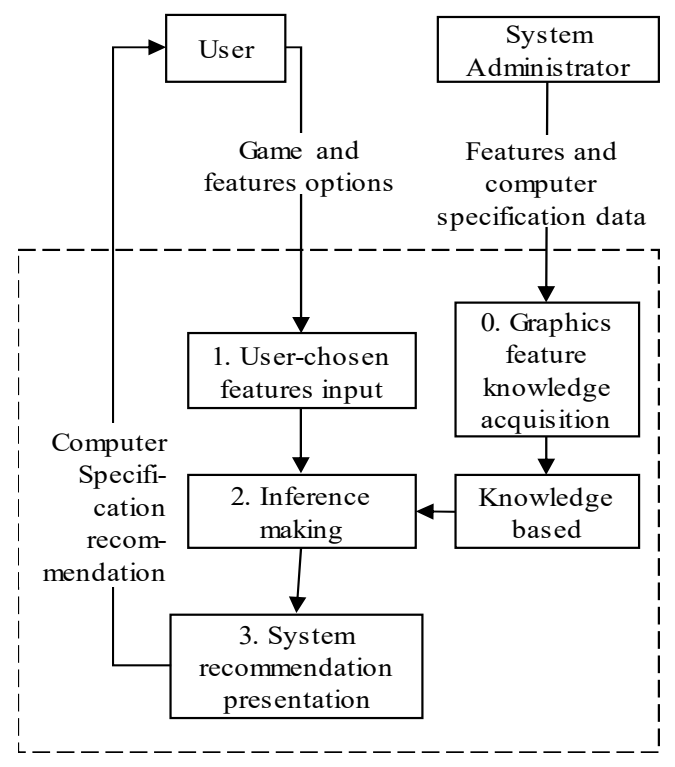

Figure 2. Data flow diagram

acquire them. The facts used to generate recommendation are graphics options selected by the user. Backward chaining inference method will prove that a goal is valid because all facts do support and are true.

As it is shown in Table 2, there are three types of computer specifications: Minimum (MIN), Medium (MED), and Maximum (MAX). It is clustered this way, by taking into account the possibility of the number of data in the knowledge base. The conclusion is calculated from the final value of features_sum variable, which is input by the user. The knowledge base is then used to draw conclusion.

The variable $\mathrm{x}$ is an object; in this case, it is a computer. It has several fields, such as CPU, GPU, and RAM. The inference engine will look up the best value of each field based on the Rule.

\section{Knowledge Base Design}

The knowledge base as a crucial part of an expert system requires data modification over time, as time flows, new hardware and other technology related to PC gaming are released.

The knowledge base itself is a database that can be altered and modified by whoever maintains the expert system. Table 3 shows the table structure in database for the list of available PC games. Table 4 shows the table structure that holds the point value for the inference engine. Table 5 represents one of the computer components, i.e. the CPU. All other components' data are stored in the knowledge base in similar way. 
TABLE 7

GENERATED RECOMMENDATION FOR THE PREFERRED GRAPHICS SETTINGS

\begin{tabular}{ll}
\hline \multicolumn{1}{c}{ Component } & \multicolumn{1}{c}{ Value } \\
\hline CPU (Intel) & Core 2 Quad Q6600 \\
CPU (AMD) & Phenom 9850 \\
GPU (Intel) & GeForce 9800 GT \\
GPU (AMD) & Radeon HD 4870 \\
RAM & 4 GB \\
Hard drive capacity & 65 GB \\
Operating system & Windows 7 64-bit \\
\hline Estimated price & 4625000 \\
\hline
\end{tabular}

\section{Application Workflow}

There are two external entities for this system: the user and the system administrator, i.e. 1) The user can choose a game that he/she likes and proceed to choose every available graphic feature in that game. Then the system computes all the input and conclusion is given to the user, which is the best price-to-performance minimum computer requirements with the estimated price per certain period; 2) The system administrator can update and modify the knowledge base. The login and authentication subsystem are not covered in this research. Figure 1 shows the context of the system and Figure 2 shows the data flow.

\section{Results and Analysis}

On the main page, the user can select one of several games and choose all available graphics options, and then the user can submit the form, as seen in Appendix Figure I and II.

The user input is then analyzed using existing knowledge base to determine the computer specification recommendation and estimated purchase costs as shown in Appendix Figure III. If after choosing the preferred graphics features, the user feels the recommendation is too expensive, data entry may be repeated from beginning to generate other combinations. Thus, the user already knows what features can be enjoyed after buying and assembling the computer in accordance with the estimated cost.

Over time, new gaming graphics and hardware technology will be developed and then released. Therefore, the knowledge base in this application will have to be dynamically changed. The knowledge base can be updated rather easily by system administrators using web interface, as seen in Appendix Figure IV, including the list of games and their graphics features, point assignment, and the list of computer specifications.

\section{Accuracy Testing}

An accuracy testing was conducted to test whether the computer specifications recommendation cal-
TABLE 8

Grand THEFT Auto V OfFicial Minimum System REQUIREMENTS

\begin{tabular}{ll}
\multicolumn{2}{c}{ REQUIREMENTS } \\
\hline \multicolumn{1}{c}{ Component } & \multicolumn{1}{c}{ Value } \\
\hline CPU (Intel) & Core 2 Quad Q6600 \\
CPU (AMD) & Phenom 9850 \\
GPU (Intel) & GeForce 9800 GT \\
GPU (AMD) & Radeon HD 4870 \\
RAM & 4 GB \\
Hard drive capacity & 65 GB \\
Operating system & Windows Vista 64-bit SP \\
& 2 \\
\hline
\end{tabular}

culated and generated by the inference engine was reasonable.

Six games and their graphics features were added into the knowledge base. They were Grand Theft Auto V by Rockstar North, Total War: Attila by Creative Assembly, Crysis 3 by Crytek, The Sims 4 by Maxis, ArmA 3 by Bohemia Interactive, and Fallout 4 by Bethesda Game Studios.

Specifications of several computer hardware (such as Intel and AMD processors, graphics processors, and hard drives with different capacities), including their price, were also added to the knowledge base. We then randomly chose a game, in this case, Grand Theft Auto V. Next, we chose the preferred level of each available graphics options, as shown in Table 6. Logically, nearly all the chosen features level is minimal, except for the texture quality and MSAA. The calculation details and the feature level point are not shown to the user.

The inference engine then analyzed the input, then looked up and tried to build the computer specifications, based on the rule base. In this case, the final value of features_sum variable was 8 (greater than 5 and less than 14). Of course, there were multiple selection of components which point were equal or close to 8 . The inference engine chose the closest ones. Table 7 shows the final recommenddation.

The NVIDIA official page [10] was then checked to confirm the minimum and recommended system requirements for GTA V. The generated recommendation matched the minimum system requirements stated there, except for the sound card, for that component was not yet included in the expert system. Table 8 shows the official system requirements.

\section{Conclusion}

Based on the result of implementation and testing of the application, it can be concluded that with this application, users can find out the minimum requirements of computer hardware and software to run a PC game with specific graphics settings favored by them by consulting as well as to an expert.

The testing shows that by preferring minimum graphics features, the total price in generated 
recommendation is reasonable enough, as it is the same as the official minimum system requirements. Due to several technical limitations during deployment, the testing could not be rerun with actual users as participants. The entire assembly is stored on https://github.com/desfree/KBS_For_PC_Gaming. Furthermore, the rules still need to be defined manually, while most recent data mining techniques could do this automatically, and the rules should be updated and managed that way.

\section{References}

[1] R. Yusuf, H. Kusniyati, Y. Nuramelia, “Aplikasi Diagnosis Gangguan Kecemasan Menggunakan Metode Forward Chaining Berbasis Web dengan PHP dan MySQL", Studia Informatika: Jurnal Sistem Informasi, vol. 9, no. 1, pp. 1-13, 2016.

[2] Z. Niswati, A. Paramita, F.A. Mustika, “Aplikasi Fuzzy Logic dalam Diagnosa Penyakit Diabetes Mellitus pada Puskesmas di Jakarta Timur", Jurnal Teknologi dan Sistem Informasi, vol. 2, no. 3, pp. 21-27, 2016.

[3] T. Larasati, M.R. Arief, "Sistem Pakar Diagnosa Awal Penyakit Kulit Kucing Berbasis Web Menggunakan Metode Certainty Factor" in Seminar Nasional Teknologi Informasi dan Multimedia 2016, pp. 13-18, 2016.

[4] J. Durkin, "Expert System Design and Development”, Upper Saddle River: Prentice Hall
International Inc, 1994.

[5] T. Williams, "The Differences Between Backward Chaining and Forward Chaining," [Online]. Available: http://trevoirwilliams.com/backwardchainingandforwardchaining/. [Accessed 8 February 2016].

[6] A. Burnes, "Grand Theft Auto V PC Graphics \& Performance Guide," NVIDIA Corporation, 21 April 2015. [Online]. Available: http://www.geforce.com/whatsnew/guides/grand-theft-auto-v-pc-graphicsand-performance-guide. [Accessed 20 June 2017].

[7] J. Atwood, "What is FXAA?" Gizmodo Media Group, 9 December 2011. [Online]. Available: http://kotaku.com/5866780/what-isfxaa. [Accessed 20 June 2017].

[8] NVIDIA Corporation, "TXAA," [Online]. Available: http://www.geforce.com/hardware/technology/txaa. [Accessed 20 June 2017].

[9] NVIDIA Corporation, "DirectX 11 Tessellation," [Online]. Available: http://www.nvidia.com/object/tessellation.html. [Accessed 20 June 2017].

[10] NVIDIA Corporation, "Grand Theft Auto V System Requirements," [Online]. Available: http://www.geforce.com/games-applications/pc-games/grand-theft-auto-v/systemrequirements. [Accessed 20 June 2017].

\section{Appendix}

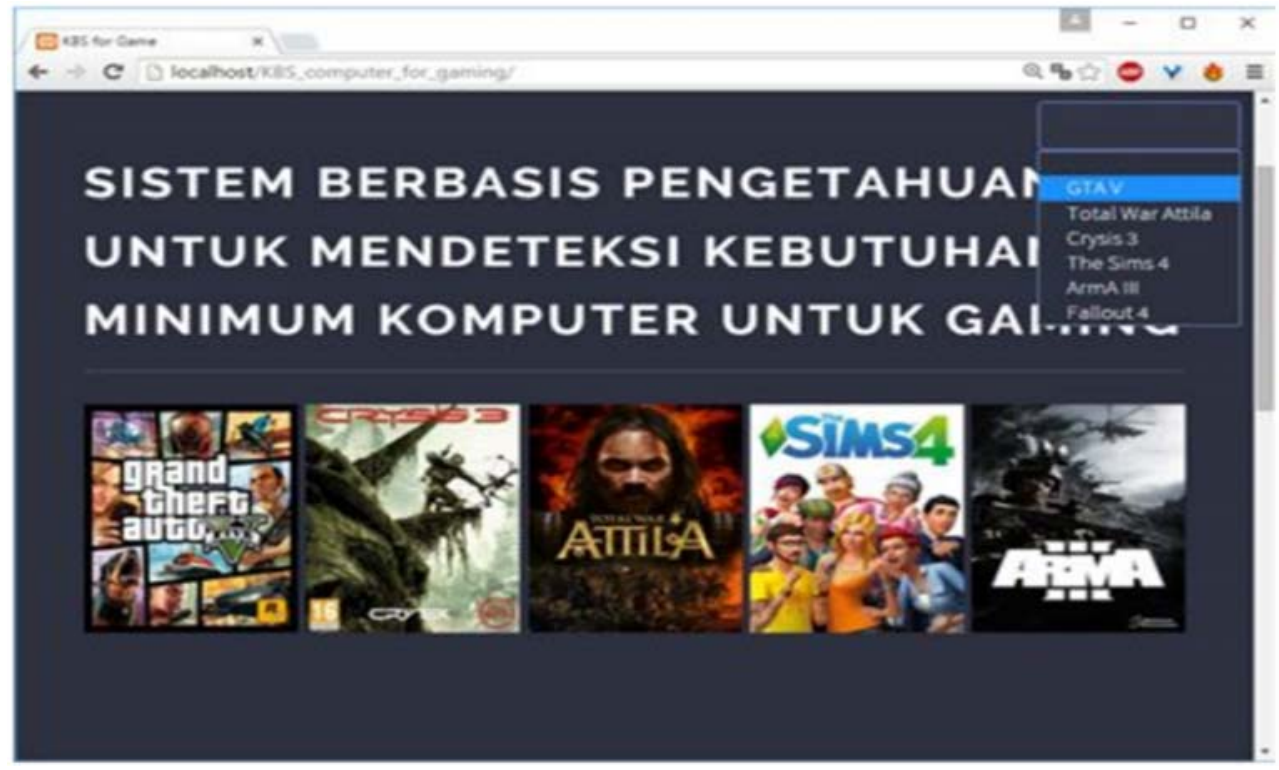

Figure 3. Game selection page 
116 Jurnal Sistem Informasi (Journal of Information System), Volume 13, Issue 2, October 2017

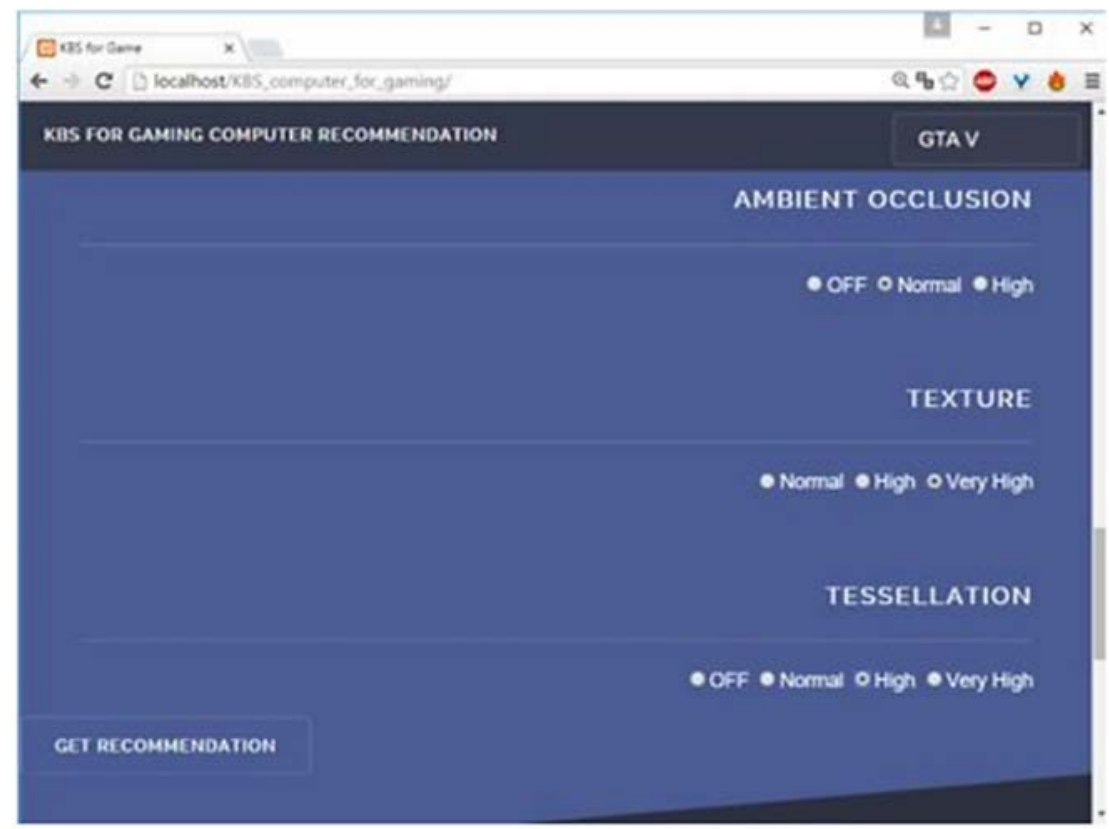

Figure 4. Features level selection page

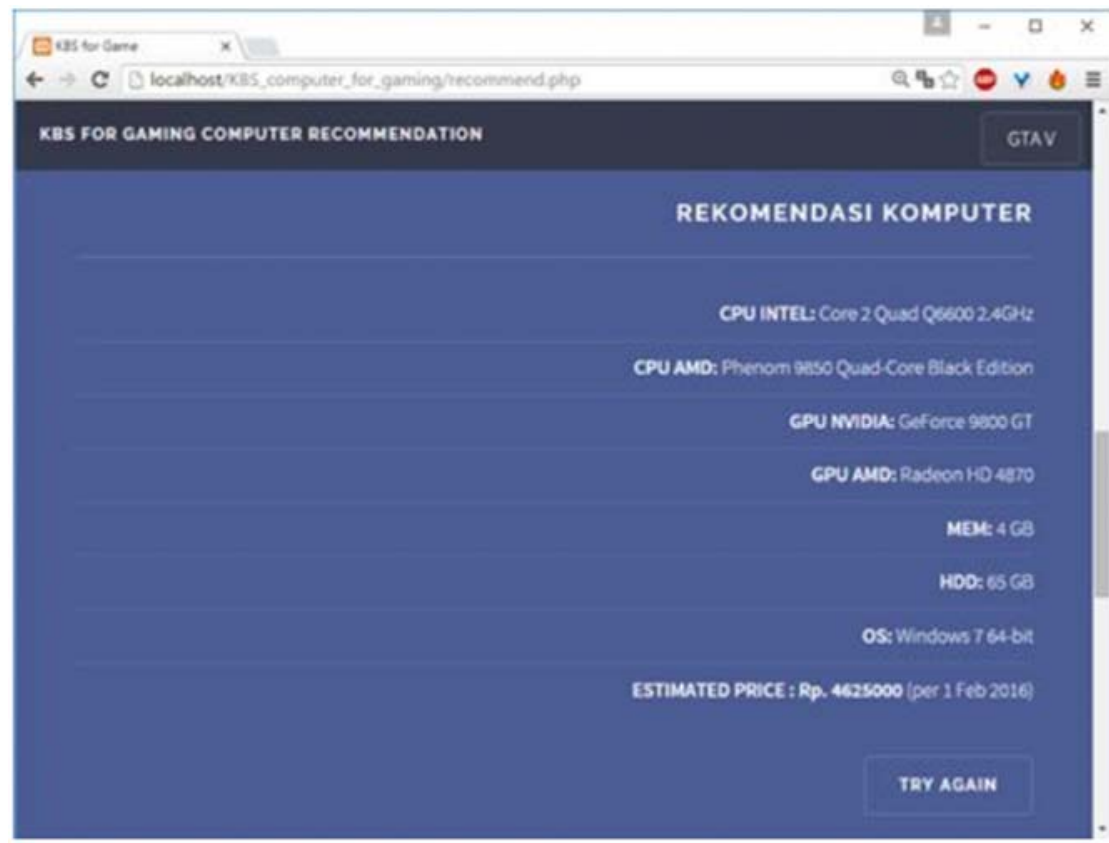

Figure 5. The recommendation page 


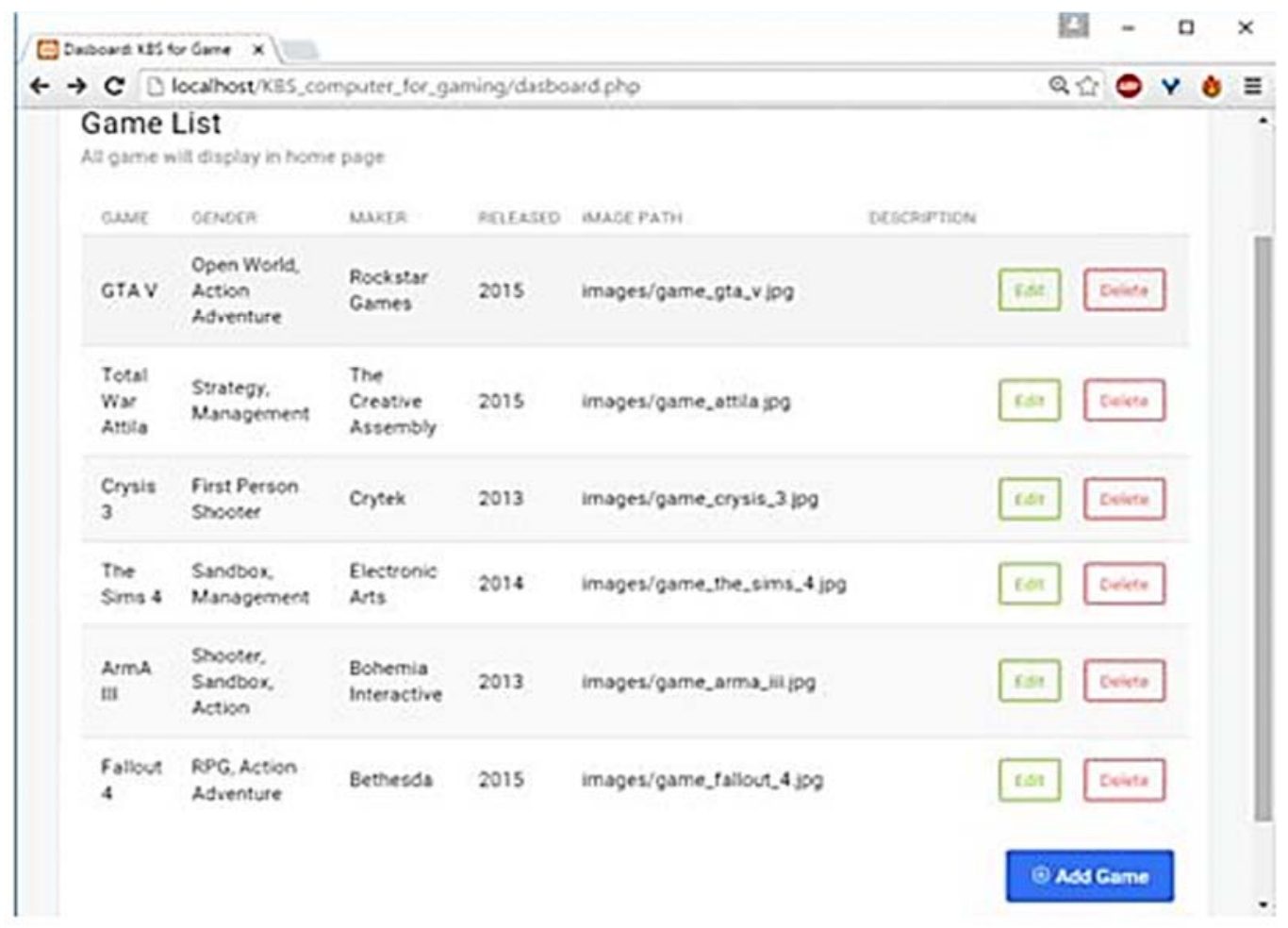

Figure 6. Knowledge renewal and modification page 